\title{
AN EMPIRICAL EVALUATION OF CHANGES IN Public Service Obligations in Spain
}

\author{
José Abreu ${ }^{\mathrm{a}}$, Xavier Fageda ${ }^{\mathrm{b}}$, Juan Luis Jiménez ${ }^{\mathrm{c}}$
}

a Universidad de Las Palmas de Gran Canaria, Spain

b Universidad de Barcelona, Facultad de Economía y Empresa, Av. Diagonal 690, 08034

Barcelona, Spain

c Universidad de Las Palmas de Gran Canaria, Facultad de Economía, Empresa y Turismo, Despacho D. 2-12, 35017, Las Palmas de Gran Canaria, Spain

\begin{abstract}
Public Service Obligations are a key mechanism for countries to improve connections among islands and remote regions with the Continent. While Public Service Obligations are allowed by the European Commission, they represent an interference with free market competition, and impact on the entrance of competitors, prices and service frequency. This study employs Canarian air market data for 2002-2015 to econometrically evaluate the effects of two changes in European policy on the number of passengers transported. The results point to the need to make market access more flexible to benefit society by generating increases in the volume of passengers moved.
\end{abstract}

Key words: Public Service Obligations; Air Transport; Spain.

JEL Code: L93, H25, L13 


\section{Introduction}

Since the process of liberalization of the European air market initiated in $1987^{1}$, a series of public interventions have aimed to enable mobility among diverse European regions. This interference in the free market has fundamentally occured through two non-exclusive mechanisms: Public Service Obligations (hereafter PSO) and traveller discounts, predominantly to residents in these regions. ${ }^{2}$

Regarding the former, the imposition of a PSO on an air route involves the regulation of market access, service levels (frequencies, seats, time schedules, type of aircraft) and prices. The aim of PSO is to guarantee the connectivity of isolated regions where air transportation is the only viable mode of transportation. PSO may also be imposed in routes that are not able to generate enough traffic to be covered by airlines with adequate service levels and fares.

The PSO's basic legislation of 1992, modified by the current Regulation (EC) $\mathrm{N}^{\mathrm{o}}$ $1008 / 2008,{ }^{3}$ has increased the number of protected routes over fourfold in the last 20 years. ${ }^{4}$

From a normative point of view, the main modification in 2008 was to define with greater objectivity when PSO can be established on a route in part of a country (see articles 16 and 18, both inclusive). According to the article 16.1:

[A] Member State, following consultations with the other Member States concerned and after having informed the Commission, the airports concerned and air carriers operating on the route, may impose a public service obligation in respect of scheduled air services between an airport in the Community and an airport serving a peripheral or development region in its territory or on a thin route to any airport on its

\footnotetext{
1 The process of air transport liberalization began in the United States with the approval of the Airline Deregulation Act in 1978. This spread to countries such as Australia, Canada, Japan and New Zealand (Cáceres, 2010). In Europe the implementation of three 'packages' of measures was carried out in 1987, 1990 and 1992 with the same end. For more information, see Regulations (CEE) $\mathrm{N}^{\circ} 3975 / 87$ and 3976/87; Directive $\mathrm{N}^{\circ}$ 87/601; Decision No 87/602; Regulations (CEE) No 2342/90, 2343/90 and 2344/90; and Regulations (CEE) $\mathrm{N}^{\circ} 2407 / 92,2408 / 92$ and $2409 / 92$.
}

2 A line of empirical research exists about this measure, above all in Europe and Spain, in the works of Calzada and Fageda (2012 and 2014), Fageda et al. (2012) and Fageda et al. (2017), among others.

${ }^{3}$ http://eur-lex.europa.eu/legal-content/EN/ALL/?uri=CELEX\%3A32008R1008

4 See the post published by Fageda, Jiménez and Valido in this context: http://nadaesgratis.es/admin/algunos-apuntes-acerca-de-la-eficiencia-de-las-ayudas-publicas-al-transportede-viajeros-en-avion 
territory any such route being considered vital for the economic and social development of the region which the airport serves. That obligation shall be imposed only to the extent necessary to ensure on that route the minimum provision of scheduled air services satisfying fixed standards of continuity, regularity, pricing or minimum capacity, which air carriers would not assume if they were solely considering their commercial interest.

In addition, Member States shall assess the necessity and adequacy of the PSO taking into account the "proporcionality between the envisaged obligation and the economic development needs of the region concerned", the existence and effectiveness of alternative modes of transport, the airfares and the "combined effect of all air carriers operating or intending to operate on the route" (art. 16.3).

Taking this into account, a typical case of a protected route by PSOs are domestic links between islands and the mainland (or between islands from a same country) where connectivity by surface or maritime transportation is difficult and/or expensive.

Any Community air carrier that meets all PSO requirements may provide scheduled air services (art. 16.8). However, if no Community air carrier provides such a PSO, the Member State may limit access to that route to a single company for up to 5 years by means of public tender (arts. 16.9 and 16.10). The winner will be entitled to compensation with an amount not to exceed "the net costs incurred in discharging each public service obligation, taking account of revenue relating thereto kept by the air carrier and a reasonable profit" (art 17.8). Thus, in some cases the imposition of PSOs is satisfied by airlines without the need of subsidies and no entry restrictions. In others, the government set an exclusivity contract with an airline that has to meet the PSO conditions regarding service levels and fares in exchange of a subsidy.

Note that PSO have to be developed within the legal framework of the European Union but, in practice, the specific implementation (selection of protected routes, the decision about the amount of subsidies, determination of fare and service levels, etc) is made by national governments.

This policy was established for the first time in Spain in 1998, when 13 PSO routes, all in the Canary Islands, were initiated. The reasons for its implementation were "the effective realization of the principle of solidarity, with particular attention to the circumstances derived from the insularity and "the need to articulate a public intervention, aimed at making possible the existence of a sufficient supply of services" (BOE, 1998). Since then 
there have been two reforms of the PSO system, in 2006 and 2011, which are the object of evaluation of this study.

These reforms represented two different changes ${ }^{5}$. Since 1998, new infrastructures had been put into service and new fleets with larger fleets had been incorporated, events that invited the PSO system to be updated to meet the real needs of users. In 2006 greater flexiblity over access to the market evolved due to an over $40 \%$ increase in demand for air transport compared to previous years. The reform also offered the firms greater freedom to adjust their offer, established a more flexible tariff system, and introduced new (generally upward) minimum requirements for frequencies and seats.

On the other hand, the 2011 modification, ${ }^{6}$ limited access to firms by offering a public tender contract for a two year period. Four of the weakest routes in the Canary Islands, deeply affected by the international crisis of 2008, had ceased to have economic interest for the only company that operated them. Such company had expressed its intention to abandon them. The contract compensated a company economically with a payment of almost five million euros, so that it would fulfill the PSO and provide a new minimum services on four routes. ${ }^{7}$

Therefore, as noted above, the aim of this study is to evaluate how Canarian air transport has been affected by these two opposing legislative changes; given that the 2006 reform was clearly pro-competition while the 2011 change was restrictive, in terms of demand. This analysis will allow us to clarify the benefits of these changes, which directly affect the General State budgets, and even form part of the parliamentary negotiation to support them.

Following this introduction, section 2 reviews the theoretical and empirical literature on PSO at island, national and European level. A legislative survey of PSO in the Canaries is carried out in section 3, while section 4 presents data and the methodological strategy. Section 5 details the main results and discusses them, and the last section draws together

\footnotetext{
${ }^{5}$ According to the Official State Bulletin, the justification in both cases is different. The 2006 reform was a response to economic changes: increases in demand, new infrastructures and companies, etc. In 2011 the system was modified due to the Binter air company abandoning four routes.

${ }^{6}$ Resolution of the Council of Ministers, 7 October 2011.

${ }^{7}$ For greater detail about the modifications established in the legislation on the minimum requirements of frequency and capacity, see tables 1 and 2.
} 
the main conclusions of the study. This result confirms what was expected: only the procompetitive reform generated increases in demand. 


\section{Literature review}

The academic literature on this topic has been predominantly empirical, with the exception, among others, of the work of Reynolds-Feighan (1995), who undertook a legislative comparison of PSO in Europe with the United States Essential Air Service (hereafter EAS) ${ }^{8}$ programme. This study argued that the administration and financing of PSO should decline in Europe in order to provide greater efficiency, transparency and regional development; and barriers to entry should similarly be identified, such as the possibility that an airline can operate a route for three years if no other company covers it (in the current legislation, 2008, the number has increased up to four/five years).

The first line of research has been descriptive, such as studies by Williams and Pagliari (2004) and Williams (2005). These works highlight the significant differences that exist regarding the use State members make of PSO, arguing that because the European Union manages them they should achieve a more efficient and equitable distribution of the subsidies (in line with Reynolds-Feighan, 1995). Merkert and O'Fee (2013) and Wittman et al. (2016) on the other hand emphasize the broad heterogeneity of the European PSO programmes, and note the different criteria employed to define a recipient route for aid, in the tariffs or in the subsidies.

In a separate piece of descriptive research, but with reference to Spain, Ramos (2015) analyzed the Canary market ${ }^{9}$. Considers that OSP minimize the potential impact of competition in the Canary Islands, and that the increase in demand observed during the period of competition between Binter and Islas Airways ${ }^{10}$ would be the result of the multiplication of trips by a small number of people rather than by the use of air transport.

One criticism of the system is that sometimes when companies are allowed to operate freely new routes are established, without the need for any aid. In this line, Betancor and Viecens (2012) find that PSO on high demand routes lack sense, given that the offer on those type of connections is guaranteed.

\footnotetext{
${ }^{8}$ This was a measure carried out in the United States to guarantee a basic air transport service for those small communities most affected by the deregulation of 1978 .

${ }_{9}^{9}$ Other works that analyze the PSOs in the Canary Islands are Hernández $(2004,2010)$

${ }^{10}$ However, Islas Airways left the market afterwards, again leaving Binter in a de facto monopoly situation. For an analysis of this exit, see Campos et al. (2015).
} 
Regarding econometric studies, Santana (2009) compares the cost of European companies that use PSO with American airlines that operate through EAS, arguing that there are indicators that the latter are more efficient than the former. Along this same line, Merkert and Williams (2013) show that European operators obtain better results in the early months of PSO contracts than when they are near their end, suggesting that airlines have less incentives to improve efficiency as contracts draw to a close due to the absence of competition on the routes.

Bubalo (2012) on the other hand focuses on the Norwegian case and argues that bidding processes are inefficient due to scarcity of competition on PSO routes, a fact that frees the dominant operator to manipulate their costs and receive larger subsidies. Pita et al. (2013) applies a model for the Azores Islands with the aim of minimizing the social costs of a PSO route and therefore establishing a more efficient system of subsidies, a work that is in the same line as Pita et al. (2014); although this latter work was in relation to Norway.

Regarding the Spanish PSO case, a pioneering article by Calzada and Fageda (2012) provides evidence how, in the 2001-2009 period, the maximum tariffs and minimum frequencies imposed on the islands by PSO translated into lower prices and greater frequencies than on the other non-regulated routes with similar characteristics, with the aim of favouring social cohesion and the development of those zones. However, in general prices are higher on routes with resident discounts. Calzada and Fageda (2014) also examined the PSO case in the five largest European air markets finding that, together, market concentration is greater on PSO routes; although when the countries are individually considered this result is only maintained in the case of Italy.

In a more recent study, Fageda et al. (2017) analyze European air routes that connect the continent with the Italian, French, Greek, Portuguese and Spanish islands. From this comparative analysis of routes with public aid (discounts and/or PSO), and without them, the authors find that European PSO policies are ineffective in controlling prices because, among other reasons, regional airlines are habitual winners in PSO call-for-tenders on the routes, thereby restricting the entrance of Low Cost Carriers.

In sum, in contrast to the existing literature, this study aims to throw light on the effects that the Agreements of 2006 and 2011 have had on the size of the Canarian air sector. For that reason, two econometrical approaches are employed in order to measure the result of both regulations. The following sections provide more detailed information about the system, the database and the empirical procedure. 


\section{PSO in Europe, Spain and the Canaries}

As previously mentioned, PSO were implemented in the European air sector in 1992, through Regulation (EEC) 2408/92, with Ireland being the first country to apply them on seven domestic routes ${ }^{11}$. In Europe there are, in April 2017, 177 PSO routes (see Figure 1). France and Greece operate 40 (22.6\% of the total) and $28(15.8 \%$ of the total) connections respectively; these are the countries with the largest number of PSO imposed in their air space. Spain occupies sixth place, with 18 PSO routes, representing $10.2 \%$ of the total. ${ }^{12}$

Figure 1. PSO by country (April 2017)

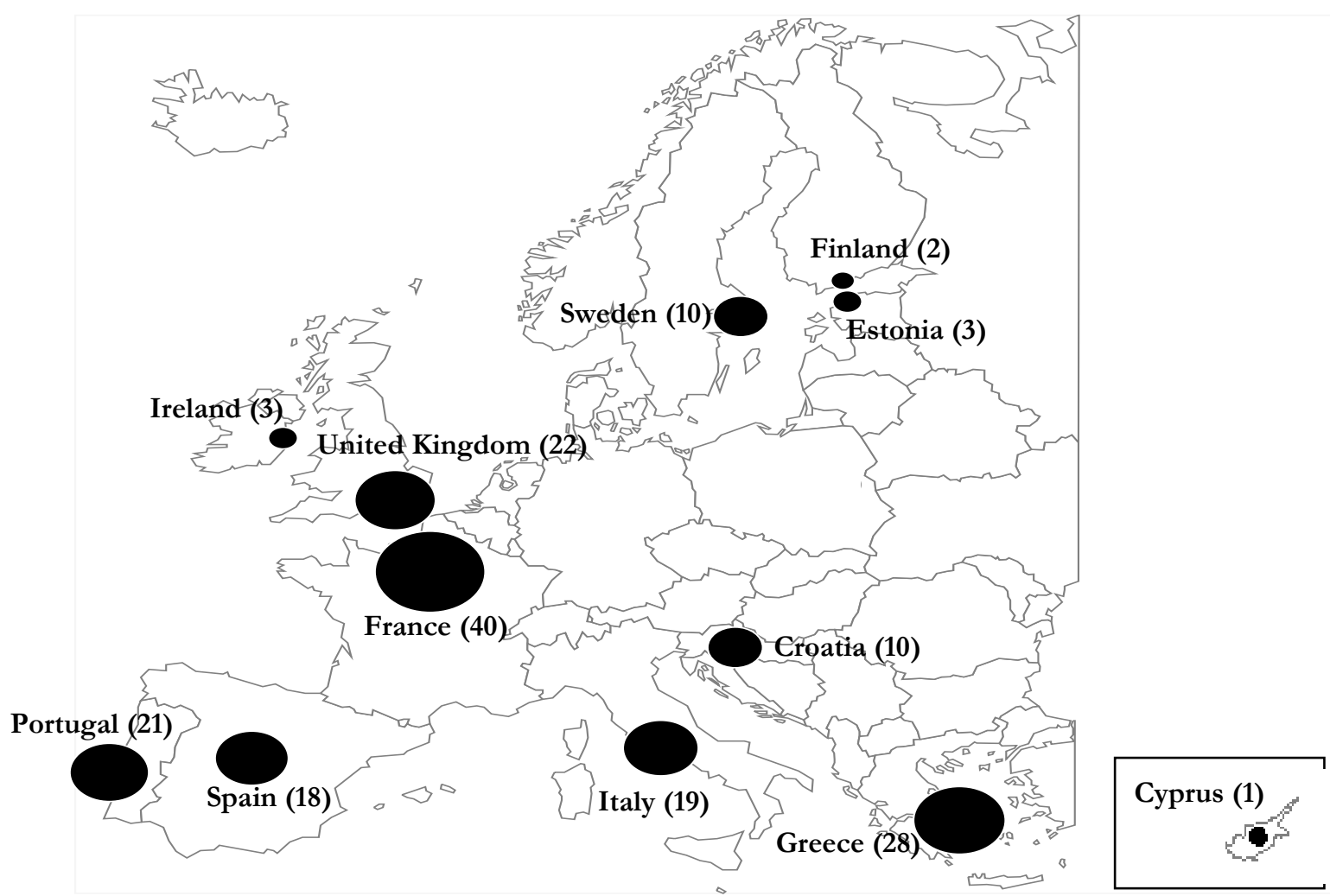

Source: Own elaboration from European Commission information. Made with Philcarto.

The first trace of Spanish legislation related to PSO can be found in Law 19/1994, which modified the Régimen Económico y Fiscal de Canarias (Economic and Tax Regime of the Canaries, hereafter, ERC). Specifically, article 5.6 states that: "with the aim of guaranteeing inter-

\footnotetext{
11 See the Commission Communication $N^{0}$ 94/C 3/03, which imposes public service obligations on specific regular air services within Ireland, 5 January 1994.

12 These are 13 in the Canary Islands, announced in 1998; 3 in the Baleares Islands, established in 2003; the Almería-Sevilla route, of 2009; and more recently in 2012, the Menorca-Madrid route.
} 
island air communications between the Canary Islands and the rest of national territory, the Government of the Nation will establish public service obligations". Later, Law 66/1997, article 103, established that it will be the Government, in a prior hearing with the Government of the Canaries and the Balearic Islands, as well as in Ceuta and Melilla, who declares PSO routes, in line with that planned in Regulation (EEC) 2408/92.

Air transport is essential for the Canary economy, as tourism is fragmented between the islands and inhabitants need mobility assistance to receive public services that are concentrated on the capital islands. Therefore, PSO have been established to apply the principle of solidarity outlined in article 138 of the Spanish Constitution. ${ }^{13}$

The Agreement of 10 July 1998 led to the announcement of PSO on 13 air routes in the Canary Islands, so that any airline could provide services on these connections, as long as it could fulfill 12 months of operational minimums on schedules, frequencies and capacity, as well as providing services within the maximum stipulated tariffs.

In 2006 , due to a more than $40 \%$ increase in demand for air transport, it was decided to modify this Agreement by offering companies greater freedom to adjust their offer, by establishing a more flexible tariff system and establishing new (generally upward) minimum requirements regarding frequencies and seats. ${ }^{14}$

However, the 2008 financial crisis led to a fall in internal demand on the Canarian Archipelago, meaning that the weakest PSO routes $^{15}$ stopped being economically attractive for the only company that was operating them (Grupo Binter), and in 2011 it announced its intention to abandon these connections.

In this situation, the eighth and ninth sections of the Agreement of 2 June 2006 meant that - when the conditions stopped being satisfied or when there existed a significant fall in demand that impeded adequate fulfilment of the aforementioned agreement - the Minister of Promotion had the powers 'to adopt appropriate measures' on the basis of article 16.9 of the Regulations (CE) 1008/2008 (previously, article 4.d of the R (CEE) 2408/92).

\footnotetext{
13 Article 138 of the Spanish Constitution says that: "The State guarantees the effective realization of the principle of solidarity [...] safeguarding the establishment of an economic equilibrium that is adequate and fair among the diverse parts of the Spanish territory, and focusing in particular on the circumstances of the islands".

${ }^{14}$ In 1998 and 2006, no special subsidy was granted to airlines, except for resident discounts.

${ }^{15}$ Gran Canaria-Tenerife South, Gran Canaria-El Hierro, Gran Canaria-La Gomera and Tenerife North-La Gomera.
} 
It was therefore decided, in the Agreement of 7 October 2011, to limit access to a single company on the previously mentioned low-demand routes. This concession of a temporary right to run a monopoly was made via public tender, for a period of two years, economically compensating ${ }^{16}$ the company with a payment of 6.2 million euros to fulfill the PSO, and run a series of new minimum services for the four previously mentioned routes. Among the requirements to be met by airlines are economic, financial, technical and professional solvency. In addition, they should be able to act; not be forbidden to hire; have fulfilled their obligations with Social Security; be aware of tax obligations; and, for foreign companies, declaration of submission to Spanish legislation.

The contract was awarded by Naysa, a Grupo Binter operator, which since November 2012 has continued to run these connections for an amount of 4.6 million euros (a 26\% reduction on the initial tender budget). In later renewals the amounts were modified: in August 2014 the subsidy was 6.15 million euros (a 0.8\% reduction) and on July 2016, those routes were again tendered for 5.58 million euros (a $0.02 \%$ reduction $)^{17}$. In all tenders, the only bidder (Naysa a regional company that operates jointly Binter, the most relevant firm) was not affected by any assumption that implies exclusion or rejection.

Therefore, since the establishment in 1998 of PSO routes in the Canaries, two normative changes have been imposed, both driven by changes in demand, but in a contrary direction: in 2006 the conditions were broadened and made more flexible (towards a less restrictive model); while in 2011-12, a subsidy for the establishment of a de facto monopoly was conceded for specific low-demand air routes.

\footnotetext{
16 According to article 17.8 of the Regulations (CE) 1008/2008, "the indemnization will not exceed the necessary amount to cover the net costs derived from the implementation of each PSO, taking into account the operator's income plus some reasonable profits".

17 Ministry of Transportation press releases of 31 October 2012 and 31 July 2014, and BOE-B-2016-12743. See also https://goo.gl/XHFw1p, https://goo.gl/JKhFtH and https://goo.gl/V6dTUA.
} 


\section{Figure 2. Chronology}
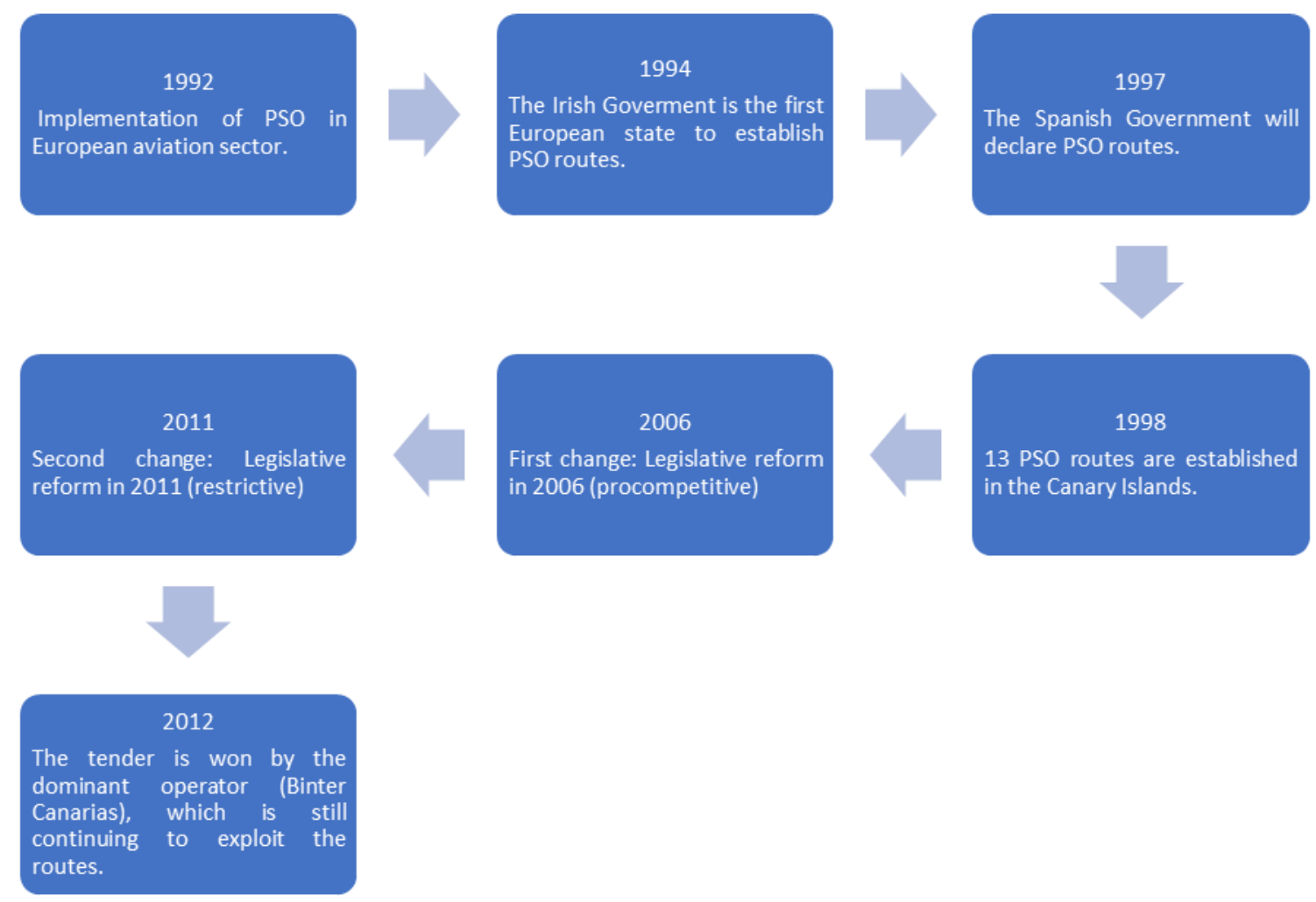

Source: Own elaboration.

In order to provide an overview of the size of the market ${ }^{18}$, in 2015 inter-island air traffic grew to 2,780,854 passengers, from 2,152,300 users in 1999. This means that, over the whole PSO period, the number of inter-island passengers grew by $29.2 \%$, despite the negative impact of the crisis (see Figure 3).

\footnotetext{
${ }^{18}$ From here on, some data referring to 2017 will be shown, but in the econometric analysis the study period goes until 2015 as we do not have data for all the variables necessary for this analysis.
} 
Figure 3. Inter-island air traffic (1999-2015)

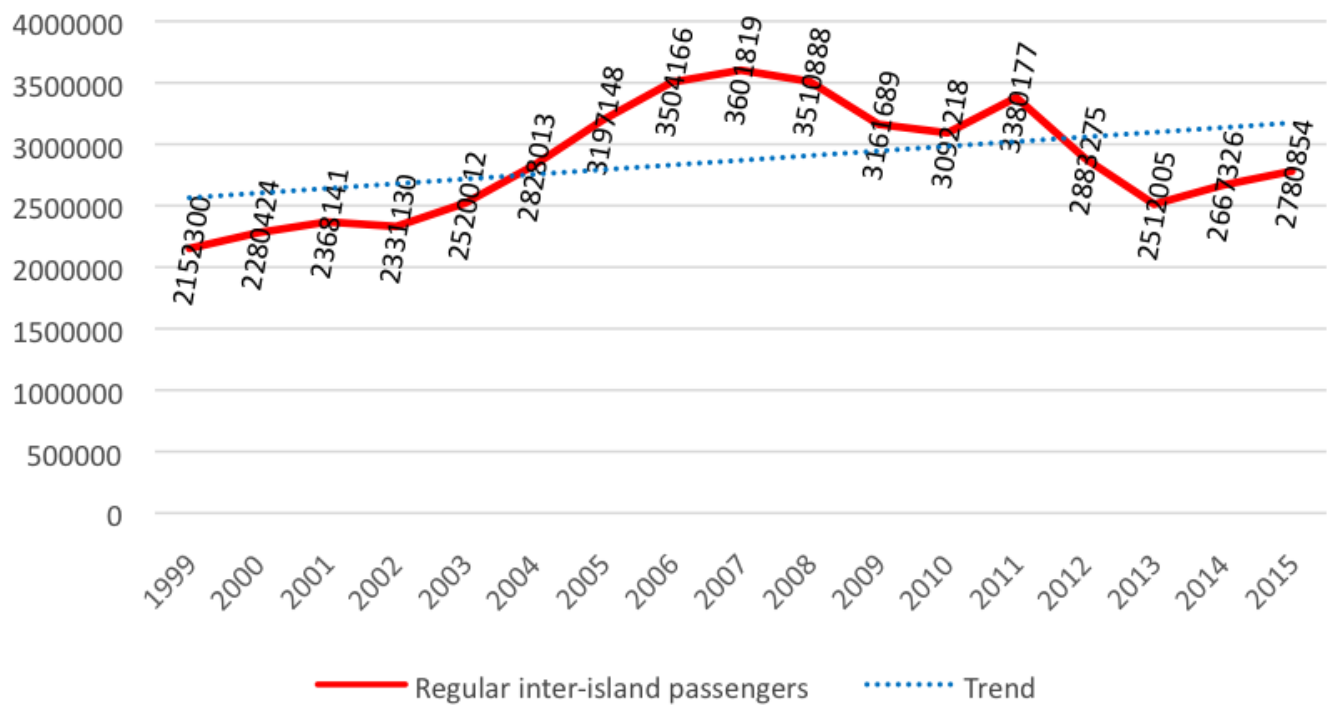

Source: Own elaboration based on ISTAC data.

Figure 4 shows in detail the 13 routes declared PSO in 1998. The broad lines represent the connections with the greatest density of passengers (more than 400,000 each year), while the routes with less traffic represent the four connections to which the reform made reference to in 2011, besides the route that links Lanzarote with La Palma. 
Figure 4. PSO routes in the Canaries and regular traffic (2015)

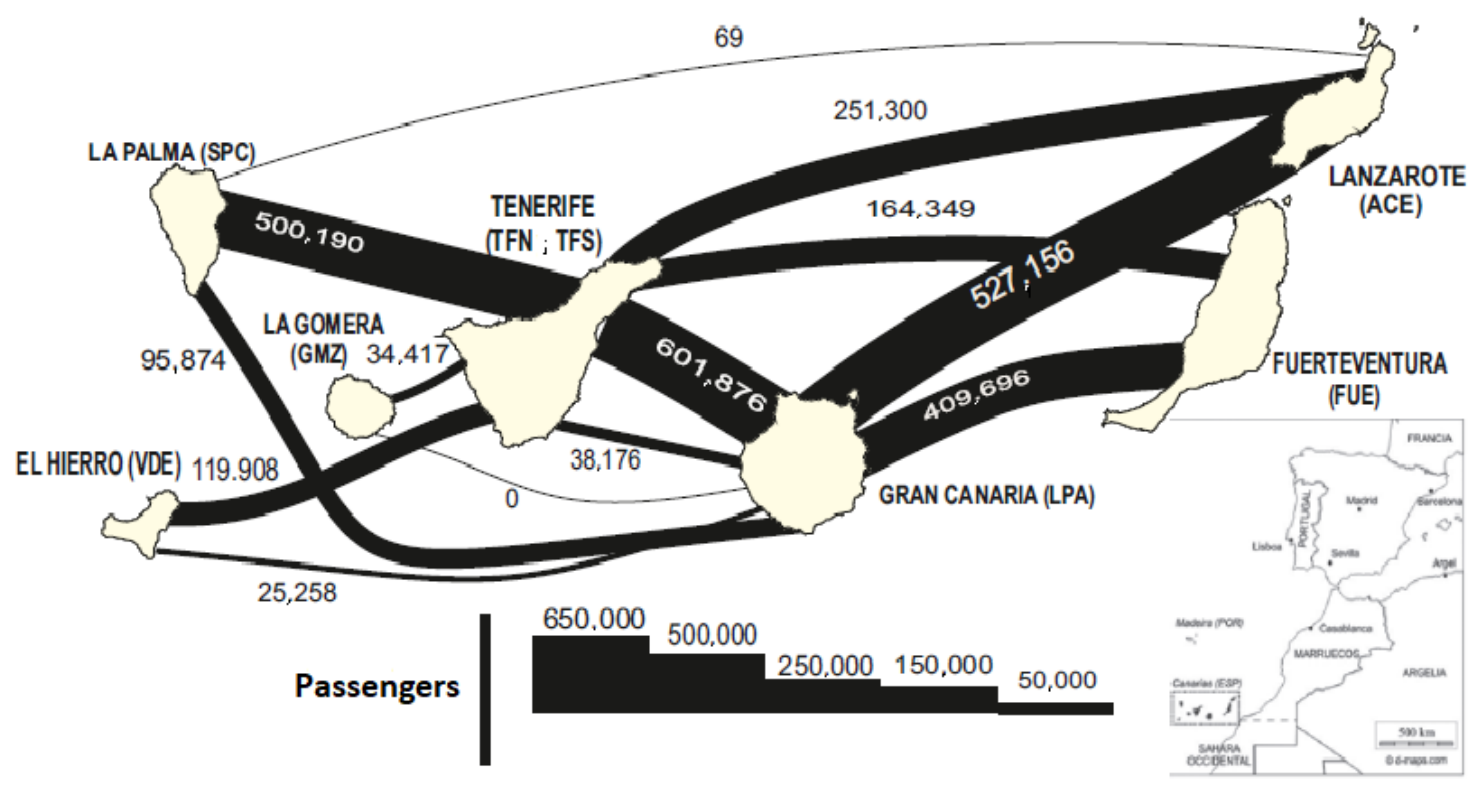

Source: Own elaboration based on ISTAC and Ramos data (2015).

Note: The airports are indicated by their IATA code.

It is necessary to highlight the fact that, besides the application of this PSO policy, the Spanish government has in recent years increased discounts on final prices on air and maritime tariffs to Canary, Baleares and Autonomous Community residents, who currently enjoy a discount of $75 \%$ on ticket prices.

On the other hand, the Canary air sector has been characterized in recent years by the outstandingly dominant position of Grupo Binter, which except during the Islas Airways period (2003-2012) and the current (2017) weak competition of CanaryFly on specific routes, practically operates as a monopoly (see Figure 5 ) $^{19}$. The other companies that operate in the Canary Islands are predominantly foreign and play a token role.

\footnotetext{
${ }^{19}$ Recently another company, Air Europa, has announced its incorporation into the Canary market, starting from October 2017.
} 
Figure 5. Market share (frequencies) of companies in the Canary Islands (2002-2015)

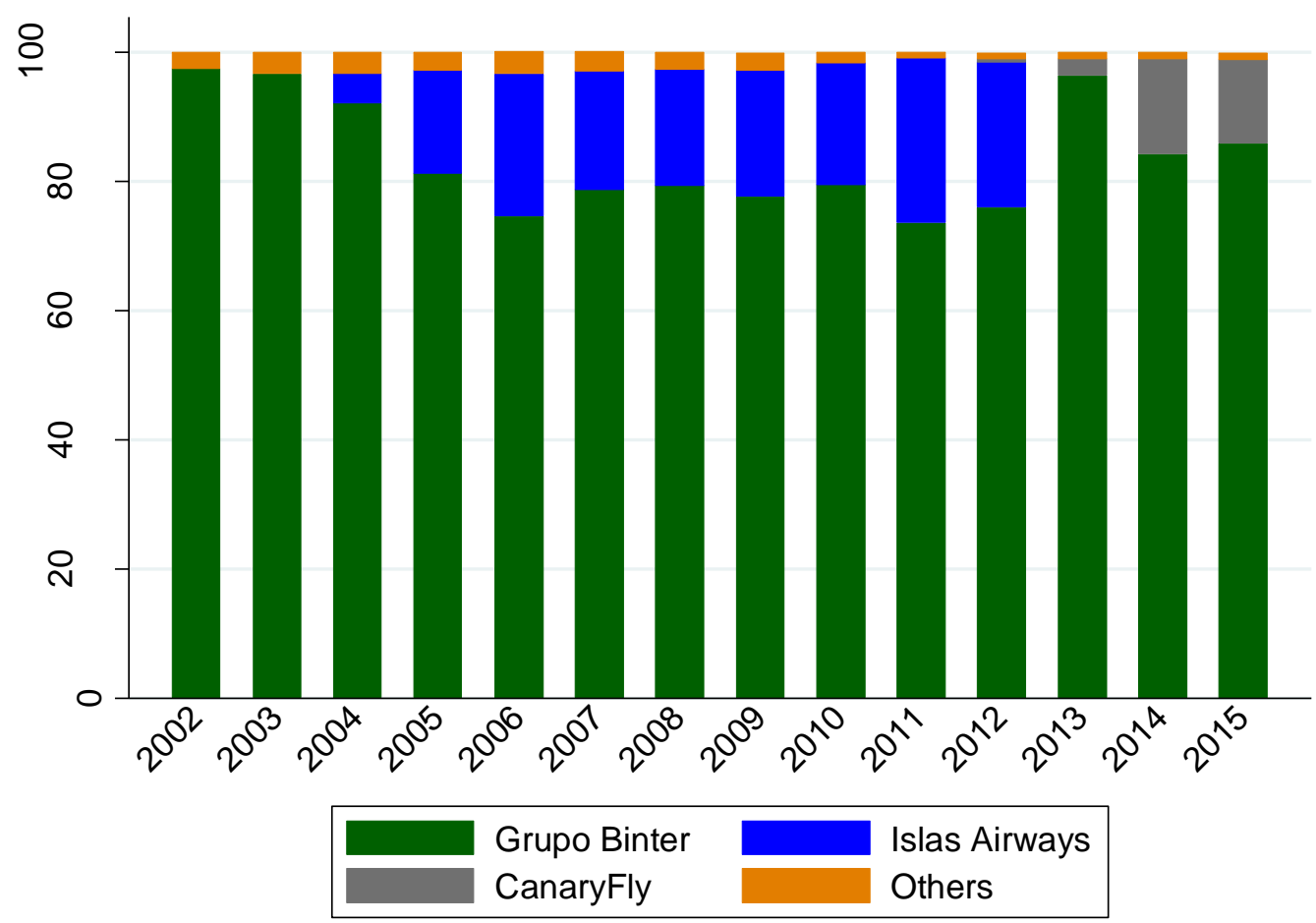

Source: Own elaboration based on RDC Aviation data. Note: No data is available for Islas Airways in 2003.

Lastly, Tables 1 and 2 show how the offer has evolved in terms of frequencies and seats, taking as a reference the minimums established in the announcements of 1998, 2006 and 2011. In 2002, Grupo Binter had already the totality of required routes specified in 1998, especially regarding frequency, although the 2003 entrance of Islas Airways into the interisland market brought with it a significant increase in the offer. In fact, in 2005 almost 65 frequencies more than the law required were offered daily, while the number of seats per week exceeded the minimum amount by almost 38,500 places. 
Table 1. Daily frequencies (single and return) by PSO route

\begin{tabular}{|c|c|c|c|c|c|c|c|c|}
\hline Route & $\begin{array}{l}\text { PSO } \\
1998\end{array}$ & 2002 & 2005 & $\begin{array}{l}\text { PSO } \\
2006\end{array}$ & 2008 & 2011 & 2013 & 2015 \\
\hline LPA-TFN ${ }^{\mathrm{a}, \mathrm{b}}$ & 24.29 & 26.42 & 28.84 & 26.77 & 35.88 & 41.38 & 30.22 & 31.18 \\
\hline TFN-SPC ${ }^{\mathrm{a}, \mathrm{b}}$ & 18.10 & 19.86 & 34.59 & 26.28 & 35.86 & 37.87 & 23.55 & 30 \\
\hline LPA-ACE $E^{a, b}$ & 15.88 & 23.26 & 20.49 & 23.32 & 31.82 & 32.84 & 24.82 & 29.53 \\
\hline LPA-FUE ${ }^{\mathrm{a}, \mathrm{b}}$ & 14.88 & 20.32 & 37.66 & 26.28 & 35.21 & 32.25 & 22.24 & 22.93 \\
\hline TFN-ACE ${ }^{a}$ & 6.45 & 9.82 & 11.54 & 10.92 & 17.85 & 13.98 & 11.39 & 11.9 \\
\hline TFN-VDE & 6.45 & 6.67 & 6.56 & 6.45 & 7.81 & 8.09 & 7.43 & 6.72 \\
\hline TFN-FUE $^{a}$ & 4.47 & 6.22 & 8.73 & 7.45 & 13.32 & 10.74 & 8.12 & 7.88 \\
\hline LPA-SPC $^{a}$ & 4.47 & 4.67 & 5.8 & 4.47 & 7.52 & 6.84 & 5.04 & 5.44 \\
\hline LPA-TFS ${ }^{a, c}$ & 4 & 6.53 & 5.47 & 4 & 7.45 & 2 & 2.98 & 2.54 \\
\hline LPA-GMZ ${ }^{\mathrm{b}, \mathrm{c}}$ & 4 & 2.67 & 4 & 4 & 4.01 & 4 & 0 & 0 \\
\hline TFN-GMZ & 2 & 4 & 4 & 4 & 3.67 & 4 & 4 & 4 \\
\hline LPA-VDE ${ }^{a, c}$ & 1 & 1.72 & 3.02 & 2.48 & 1.84 & 2 & 2.05 & 2.01 \\
\hline ACE-SPC & 0.57 & 0.28 & 0.47 & 0.85 & 0.28 & 0.21 & 0.04 & 0.03 \\
\hline Total & 106.56 & 132.44 & 171.17 & 147.3 & 202.52 & 196.20 & 141.88 & 154.2 \\
\hline
\end{tabular}

Source: Own elaboration based on RDC Aviation, BOE data (1998, 2006 and 2011) and Ramos (2015).

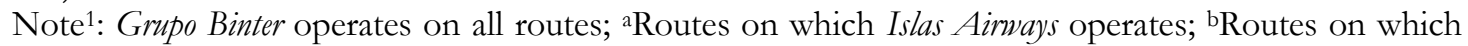
Canary Fly operates; ${ }^{c}$ Routes affected by the 2011 regulatory change.

Note2: CanaryFly offered services on the LPA-GMZ route in 2012 until Naysa's award of operations (Grupo Binter).

An increase in demand brought with it a revision of PSO in 1998, establishing minimum requirements that were raised higher in 2006. In 2008 the offer exceeded the threshold of the new declaration, but from 2011 the effects of the economic crisis started to be noticed and there was a fall in demand, along with a declining tendency in both frequencies and seats. This fall was confirmed in 2013; driven also by the ceasing of Islas Airways operations.

It can be seen that on some key routes the offer is below PSO criteria established in 2006. This is legal, however, due to a clause (section nine in the Appendix) that allows a reduction in the parametres of quality during two consecutive seasons of IATA Traffic, at which time a new Agreement would have to be approved. The entrance of CanaryFly into the market has seen a return to the minimum levels of 2006, as can be seen in 2015, 
although there are routes that currently do not have connections, such as the LPA-GMZ line, or are very weak (ACE-SPC).

Table 2. Weekly seats (single and return) by PSO route

\begin{tabular}{|c|c|c|c|c|c|c|c|c|}
\hline Route & $\begin{array}{l}\text { PSO } \\
1998\end{array}$ & 2002 & 2005 & $\begin{array}{l}\text { PSO } \\
2006\end{array}$ & 2008 & 2011 & 2013 & 2015 \\
\hline LPA-TFN ${ }^{\mathrm{a}, \mathrm{b}}$ & 11,538 & 10,950 & 15,287 & 13,231 & 21,398 & 20,804 & 15,275 & 16,114 \\
\hline TFN-SPC ${ }^{\mathrm{a}, \mathrm{b}}$ & 8,462 & 8,527 & 17,041 & 13,000 & 17,993 & 18,944 & 11,901 & 14,536 \\
\hline LPA-ACE $E^{\mathrm{a}, \mathrm{b}}$ & 7,500 & 10,221 & 12,980 & 11,885 & 18,106 & 16,603 & 12,356 & 14,738 \\
\hline LPA-FUE ${ }^{\mathrm{a}, \mathrm{b}}$ & 7,115 & 8,847 & 18,935 & 13,000 & 18,750 & 16,231 & 10,970 & 10,405 \\
\hline TFN-ACE & 3,096 & 4,220 & 5,945 & 5,538 & 8,681 & 7,018 & 5,757 & 6,013 \\
\hline TFN-VDE & 3,000 & 2,860 & 3,315 & 3,077 & 3,891 & 4,086 & 3,755 & 3,398 \\
\hline TFN-FUE $^{a}$ & 2,115 & 2,659 & 4,416 & 3,788 & 6,619 & 5,394 & 4,047 & 3,985 \\
\hline LPA-SPC & 2,115 & 2,001 & 2,872 & 2,250 & 3,840 & 3,477 & 2,580 & 2,838 \\
\hline LPA-TFS ${ }^{a, c}$ & 1,904 & 1,238 & 3,961 & 1,096 & 5,082 & 981 & 1,921 & 1,682 \\
\hline LPA-GMZ ${ }^{\mathrm{b}, \mathrm{c}}$ & 1,904 & 321 & 1,157 & 519 & 957 & 519 & 0 & 0 \\
\hline TFN-GMZ & 942 & 482 & 1,157 & 519 & 490 & 519 & 2,022 & 2,022 \\
\hline LPA-VDE ${ }^{a, c}$ & 135 & 292 & 990 & 423 & 917 & 692 & 1,036 & 1,016 \\
\hline ACE-SPC & 135 & 120 & 383 & 262 & 269 & 108 & 7 & 32 \\
\hline Total & 49,961 & 52,738 & 88,439 & 68,588 & 106,993 & 95,376 & 71,627 & 76,779 \\
\hline
\end{tabular}
(2015).

Note': Grupo Binter operates on all routes; aRoutes on which Islas Airways operated; bRoutes on which CanaryFly operates; cRoutes affected by the regulatory change of 2011.

Note2: CanaryFly offered services on the LPA-GMZ route in 2012 until Naysa's operating award.

Finally, although we do not have information on effective airfares, Table 3 shows the airfares of a one way ticket that have been applied through PSO. In general, a higher airfare is associated with greater distances and less competition.

At all rates it is necessary to apply the resident discount of $75 \%$ since June 2017 , replacing the previous discount of 50 percent. This policy has been applied in Spain since 1960 when a discount of $12 \%$ was established for air transport to residents of the Canary Islands with the rest of the national territory. Two years later it increased to 33 percent. In 1987, a resident discount of 10\% was established for inter-island flights. From 1998 to 2004 this subsidy for inter-island flights was $33 \%$, while a progressive discount was subsequently applied in 2005 and 2006 of 38\% and 45\% respectively (Fageda et al., 2016). 
Having said that, in 1998, maximum airfares were applied for each of the routes that could be reviewed annually by the Ministry of Public Works and Transport on the basis of the anual evolution of Consumer Price Index (CPI). Likewise, in the event of abnormal, unpredictable and non-transportable increases in cost elements affecting the operation of these air services, and at the proposal of the airlines, the Ministry of Public Works and Transport may modify the maximum rate in proportion to the cost increase experienced. Such modification shall be notified to the European Commission for publication in the OJEU. Promotional and basic airfares may be established provided the levels do not exceed the maximum limits indicated. (BOE, 1998).

On the other hand, in 2006, reference airfares were established (the lowest rate without conditions, in column 3). From this reference airfares promotional, flexible and social airfares could be established.

So, the promotional airfares are that airfare established by the company with a discount of at least $10 \%$ over the reference airfare. Companies may set flexible airfares as long as the price of the resulting air fare does not exceed certain percentages of the reference air fare: during 2006, it may not exceed 20 percent; and starting in 2007, 25 percent. In any case, the number of seats occupied in each flight with these airfares, will not exceed $50 \%$ of the seats offered. Further, companies will be obliged to set social airfares at reduced prices compared to the reference airfares, at least for the following categories of passengers: young people under the age of twenty-two, for university students under the age of 27 residing in the non-capital islands, persons who have reached the age of sixty-five, and federated teams in official competitions in the Canary Islands (in 1998, patients who needed hospital assistance in the capital islands from non-capital islands were also named). Discounts applied to the prices of these tariffs shall not be less than $10 \%$ of the reference tariff prices (BOE, 2006).

It should be noted that the Spanish legislation on PSO indicates that in case the companies operating a route recorded in the summer and winter periods a coefficient set that exceeds $75 \%$ occupancy, should increase frequencies to lower that level or reduce promotional and social airfares by $15 \%$ compared to reference airfares, with the connotations that it has for the profitability of the airlines, that would be operating with excess capacity. 
Table 3. Regulated airfares of a one way ticket (euros) by PSO route (2017)

\begin{tabular}{|c|c|c|c|c|c|c|}
\hline Route & $\begin{array}{l}\text { PSO } \\
1998\end{array}$ & $\begin{array}{l}\text { PSO } \\
2006\end{array}$ & $\begin{array}{l}\text { PSO } \\
2011\end{array}$ & $\begin{array}{c}\text { Distance } \\
(\mathbf{K m})\end{array}$ & $\begin{array}{l}\text { Travel } \\
\text { Time } \\
\text { (min.) }\end{array}$ & Operator \\
\hline LPA-TFN ${ }^{\mathrm{a}, \mathrm{b}}$ & $40.27(61.13)$ & $52(62.09)$ & & 110 & 30 & $\begin{array}{c}\text { Binter } \\
\text { Canarias/ } \\
\text { CanaryFly }\end{array}$ \\
\hline TFN-SPC ${ }^{a, b}$ & $43.27(65.68)$ & $55(65.67)$ & & 140 & 30 & $\begin{array}{c}\text { Binter } \\
\text { Canarias / } \\
\text { CanaryFly } \\
\text { Binter }\end{array}$ \\
\hline LPA-ACE $E^{a, b}$ & 55.29 (83.93) & $67(80)$ & & 208 & 45 & $\begin{array}{c}\text { Canarias/ } \\
\text { CanaryFly } \\
\text { Binter }\end{array}$ \\
\hline LPA-FUE ${ }^{\mathrm{a}, \mathrm{b}}$ & 48.08 (72.99) & $60(71.64)$ & & 159 & 40 & $\begin{array}{c}\text { Canarias/ } \\
\text { CanaryFly } \\
\text { Binter }\end{array}$ \\
\hline TFN-ACE ${ }^{a}$ & $\begin{array}{c}73.92 \\
(112.21)\end{array}$ & 88 (105.07) & & 272 & 50 & $\begin{array}{c}\text { Canarias / } \\
\text { CanaryFly } \\
\text { Binter }\end{array}$ \\
\hline TFN-VDE ${ }^{a}$ & 48.08 (72.99) & 60 (71.64) & & 169 & 40 & $\begin{array}{c}\text { Canarias/ } \\
\text { CanaryFly } \\
\text { Binter }\end{array}$ \\
\hline TFN-FUE $^{a}$ & $\begin{array}{c}68.52 \\
(104.01)\end{array}$ & 83 (99.10) & & 241 & 50 & $\begin{array}{l}\text { Binter } \\
\text { Canarias/ } \\
\text { CanaryFly }\end{array}$ \\
\hline LPA-SPC $^{a}$ & $\begin{array}{c}67.61 \\
(102.63)\end{array}$ & 82 (97.91) & & 245 & 50 & $\begin{array}{c}\text { Binter } \\
\text { Canarias/ } \\
\text { CanaryFly }\end{array}$ \\
\hline LPA-TFS ${ }^{a, c}$ & $40.27(61.13)$ & $52(62.09)$ & n.a. & 117 & 40 & $\begin{array}{c}\text { Binter } \\
\text { Canarias }\end{array}$ \\
\hline LPA-GMZ ${ }^{\mathrm{b}, \mathrm{c}}$ & $\begin{array}{c}67.61 \\
(102.63)\end{array}$ & 82 (97.91) & n.a. & 169 & n.a. & $\begin{array}{c}\text { Binter } \\
\text { Canarias }\end{array}$ \\
\hline TFN-GMZ & $48.08(72.99)$ & $60(71.64)$ & 70 (72.94) & 86.1 & 30 & $\begin{array}{c}\text { Binter } \\
\text { Canarias }\end{array}$ \\
\hline LPA-VDE ${ }^{a, c}$ & $\begin{array}{c}73.32 \\
(111.30)\end{array}$ & 88 (105.07) & 104 (108.4) & 246 & 55 & $\begin{array}{c}\text { Binter } \\
\text { Canarias }\end{array}$ \\
\hline ACE-SPC & $\begin{array}{c}84.14 \\
(127.72)\end{array}$ & 88 (105.07) & & 406 & n.a. & $\begin{array}{c}\text { Binter } \\
\text { Canarias }\end{array}$ \\
\hline
\end{tabular}

Source: Own elaboration based on BOE data (1998, 2006 and 2011), Ministry of Public Works and Transport press releases 2016 and WebFlyer. Airfares have been updated to euros from January 2017 on the basis of the consumer price index for comparison in brackets; n.a: not available.

Note': Grupo Binter operates on all routes; ${ }^{2}$ Routes on which Islas Airways operated; bRoutes on which CanaryFly operates; cRoutes affected by the regulatory change of 2011.

Note $^{2}$ : CanaryFly offered services on the LPA-GMZ route in 2012 until Naysa's operating award.

Overall, the regulated prices (updated to euros of January 2017 to take into account inflation) have remained stable over time. However, we cannot assess properly the impact 
of the different normative changes by means of an econometric analysis because we do not have data on the effective prices charged by airlines.

Have these normative changes, which have had a direct impact on the air market, achieved the objective of maintaining or improving mobility on the Islands, in terms of passengers moved? The fourth and fifth section will empirically study this question.

\section{Data}

In order to evaluate the effects of the two normative changes we have collected annual data on 22 inter-island routes for 2002-2015 concerning diverse variables of interest relative to the air sector, socioeconomic and geographic, gathered through sources such as RDC Aviation, the Instituto Canario de Estadística (henceforth, ISTAC) or via own elaboration. The variables employed in the analysis are detailed here:

(i) Passengers $k_{k, t}$ : total number of annual passengers moved (single and return) on the route $k$ for year $t$. This is the endogenous variable of the model. Source: RDC Aviation.

(ii) Population $k$ : : this is the average population between the island of origin and destination on route $k$ for year $t$, and it seeks to capture the scale of market potential in terms of inhabitants on each route. Source: ISTAC.

(iii) Rate of employment ${ }_{k, t}$ : this is constructed using the average employment rate (in \%) between the island of origin and destination on route $k$ for year $t$. It is a proxy of the economic situation of cities that make up the route. Source: ISTAC.

(iv) $D i D_{k, t}^{2006}{ }^{62011}$ : this is the estimator for differences-in-differences and is a binary variable that takes value 1 for the treatment group (route) in the period immediately after the regulatory change. This variable shows how the number of passengers varies for PSO routes affected by the regulatory changes of 2006 and 2011 in contrast to the rest. In order to do this analysis, we have to include year effect and estimate panel data by using fixed effect. Source: Own elaboration and Albalate (2008).

The descriptive statistics corresponding to the database can be found summarized in Table 4. 
Table 4. Descriptive statistics

\begin{tabular}{lccccc}
\hline Variable & Observations & Media & $\begin{array}{c}\text { Standard } \\
\text { deviation }\end{array}$ & Minimum & Maximum \\
\hline $\begin{array}{l}\text { Regular } \\
\text { passengers }\end{array}$ & 251 & 167.362 & $217.683,9$ & 25 & 725.031 \\
Population & 251 & $439.302,3$ & 204.030 & $47.176,5$ & 879.473 \\
Employment rate & 251 & 48,34 & 5,24 & 39,12 & 61,02 \\
Distance & 251 & 204,5 & 94,53 & 59,6 & 437,23 \\
\hline
\end{tabular}

Source: Own elaboration.

Nota: Six routes have been eliminated either because public data on passenger traffic is unavailable, or because it is zero.

The number of observations rises to 251 on routes of between 59 and 437 kilometres of distance. The average number of annual passengers is 167,362 . On the other hand, the average population between the routes is 439,302 inhabitants. The average rate of employment is moderate, at $48.34 \%$. The majority of the maximum values correspond to the route between the two capital islands: Gran Canaria and Tenerife (North). 


\section{Empirical strategy}

With the aim of analyzing the effects of the two normative changes over the described endogenous, and given the structure of the database, the empirical strategy consists in an estimation of the panel data model. ${ }^{20}$ Besides this, we apply an estimation of complementary causal effects consisting in the matching analysis, as is detailed below.

It is important to highlight the need to divide the sample into two periods, with the aim of identifying the effect of each policy. The estimations are made at route level, employing as endogenous the annual volume of passengers moved, to analyze the effects of the two regulatory changes of 2006 and 2011, controlling for distinct factors. The equations to estimate are [1] and [2]. The first one estimates the effects of the procompetitive change of 2006:

$$
\ln \left(\text { Passengers }_{k, t}\right)=\beta_{0}+\beta_{1} \ln \text { Population }_{k, t}+\beta_{2} \ln \text { Employment }_{k, t}+\beta_{3} \text { DiD }_{k, t}^{2006}+\beta_{i=3}^{15} \text { Year Effect }_{t}+\varepsilon_{k, t}
$$

Equation [2] is employed for the restrictive modification of 2011:

$$
\ln \left(\text { Passengers }_{k, t}\right)=\beta_{0}+\beta_{1} \ln \text { Population }_{k, t}+\beta_{2} \ln \text { Employment }_{k, t}+\beta_{3} \text { DiD }_{k, t}^{2011}+\beta_{i=3}^{15} \text { Year Effect }_{t}+\varepsilon_{k, t}
$$

where the subindex $k$ denotes the route, $t$ the year and $\varepsilon_{k, t}$ is the error term. "Fixed effects by year" have been added in order to capture the temporal impacts that are common on all routes and "fixed effects by route" estimation to control for omitted variables that do not change in time.

In general, the demand for air transport is usually modelled as a gravitational equation in which demand depends positively on the population and income of both cities/regions and negatively on the distance between both cities/regions. For that reason, we include as explanatory variables the average of the population and the rate of employment of the islands of origin and destination.

Given that we include fixed route effects, the econometric estimation exploits the variation within the data. Therefore the fixed route effects capture the effect of distance that does not vary in time (and that therefore we cannot include in the regression). On the other

\footnotetext{
${ }^{20}$ Despite that, we have undertaken estimations of the equations 1 and 2, but eliminating the frequency as explanatory, through the data pool. The estimator for differences coincides in significance and sign with the results that show both the panel data and the matching. Results upon request.
} 
hand, the fixed effects of route and time can collect a large part of the effect related to the population and employment rate.

As has been pointed out above, the main characteristic of the empirical strategy is that an estimator for differences is employed; an appropriate technique when the "treatment" or non-random regulatory change is considered. In this case the application is undertaken using panel data, with fixed effects (see the technical justification for this case in, for example, Albalate, 2008). The panel is not balanced, as it does not contain all the routes at all moments in time. With this, control over the non-observed heterogeneity between routes and in time is sought.

With an analysis prior to the results it is interesting to confirm, through a test of averages on the treatment group (see Tables 4 and 5), whether effectively in the period posterior to the regulations of 2006 and 2011 the PSO routes have modified the volume of passengers with respect to the untreated connections (control group).

Table 5 brings together analysis for the 2002-2009 period, but differentiates behaviour between routes affected by the normative change of 2006 versus those that were not affected. As can be seen, the average values of the passenger variable increased by $21 \%$ on the routes affected by the change, as the control group fell by $59 \%$. However neither of the two average tests applied show statistical significance between periods.

Table 5. Passengers. Average values and T-test. First change PSO (2006)

Before $2006 \quad 2006-2009 \quad$ t-test

Treated routes $\quad 215,166 \quad 260,374 \quad-0.9523$

$\begin{array}{lll}\text { Control group } \quad 13,147 & 7,783 & 1.4966\end{array}$

Source: Own elaboration.

Regarding the second change, behaviour in both groups shows a reduction in the average volume of passengers, but with notable differences. While the control group saw passengers reduced by almost $20 \%$, the routes affected saw a fall of $33 \%$. Furthermore, this latter difference is statistically significant, between periods. 
Table 6. Passengers. Average values and T-test. Second change PSO (2011)

\begin{tabular}{lccc} 
& 2009-2011 & 2012-2015 & t-test \\
\hline Treated routes & 38,762 & 26,233 & $2.0824 * *$ \\
& & & \\
Control group & 222,966 & 181,130 & 0.8042 \\
& & & \\
\hline Surce: Own elaboration. ${ }^{* *}$ Significance test $(5 \%)$. &
\end{tabular}

However, it is important to note that causality cannot be inferred from these results, given that it is necessary to control for other factors. In order to address this causal relationship, we apply the panel analysis outlined in the previous section.

\section{Results}

The estimations of the panel data model with fixed effects (necessary to apply the difference-in-difference estimation) can be found in Table 7. As was mentioned in the previous section, we divide the sample into two periods, with the aim of better identifying the effect of each policy in time, given that the effects of both policies overlap for some routes in the last period.

The panel analysis with fixed effects allows us to consider the non-observable heterogeneity of the individuals that make up the sample that, in our case, are the different routes from the database. Further, the estimation with fixed effects allows us to focus on the changes in traffic (and unrelated with the policies under consideration). In effect, in terms of policy evaluation, the relevant point is the change in the level of traffic and not the average levels of traffic.

The control variables are not statistically significant, which might be explained by the fact that the variation within is not high in a way that the fixed effects of the route already capture their effect on the traffic.

The variable of interest is the coefficient of the difference-in-difference estimator, which we recall takes value 1 for the affected routes following the normative change, and is shown in Table 7. 
Table 7. DiD. Passenger's equation. Panel data, fixed effect.

\begin{tabular}{lcc}
\hline & $\begin{array}{c}\text { First change: Legislative reform } \\
\text { in 2006 (procompetitive) }\end{array}$ & $\begin{array}{c}\text { Second change: Legislative } \\
\text { reform in 2011 (住trictive) }\end{array}$ \\
\hline Difference-in-difference & $0.98(0.22)^{* * * *}$ & $0.18(0.33)$ \\
Ln Population & $1.86(2.79)$ & $17.67(12.34)$ \\
Ln Employment & $1.56(3.74)$ & $1.74(4.38)$ \\
Year effect & Included & Included \\
Constant & $-19.33(43.01)$ & $-224.66(154.09)$ \\
\hline Observations & 134 & 98 \\
Overall $\mathrm{R}^{2}$ & 0.36 & 0.26 \\
\hline
\end{tabular}

Note: $* * * 1 \%, * * 5 \%, * 10 \%$ significance test. Standard errors in brackets.

In general, the goodness of fit in both models is high. But the relevant variable, the binary of the difference-in-difference, shows two opposing results. The 2006 policy of making entrance more flexible and, in general, applying a more procompetitive focus, generated a notable increase in passengers of $98 \%$. However, this result must be tempered by the knowledge that information on prices is not available; a relevant variable in the estimation of demand models such as the proposed, but without invalidating the result.

For its part, the variable of the 2011 policy that restricted entrance on the affected routes also carried with it an increase in traffic, but without statistical significance.

Therefore, the 2006 reform allowed traffic to double in comparison with the control routes. In this sense, the combination of both measures (to impose higher frequencies and relax the price restrictions) seems to have had a positive effect on the volume of passengers on the affected routes.

One possible explanation for this result is that greater frequencies involve an increase in quality via a reduction in the so-called waiting time (the difference between the schedule desired and the flight) and probably the flexibility of tariffs allowed higher prices to be charged to passengers who are less sensitive to price and lower prices to passengers who are more price sensitive.

On the other hand, the 2011 reform that involved restricting entrance in exchange for a subsidy to the airline that won the contract does not seem to have had such positive 
effects. However, the fall in traffic on the routes affected by the policy could have been significant without the subsidies as there were no airlines interested in offering flights in market conditions. Another question is whether the size of the subsidy justifies the policy as its effects on traffic appear to have been modest.

In order to test these results, we implement another complementary empirical strategy, the matching estimator. Academic literature has been referred to as unconfoundedness, exogeneity, ignorability or selection on observables when regression models have been used. However, comparisons made between treated and control groups remove any selfselection bias. Adjusting treatments and control groups for differences in covariates, or pretreatment variables, is the key to obtaining causal inference of effects, as matching analysis seeks to do (see Rubin, 1974 or Rosenbaum and Rubin, 1983).

Let $Y_{1}$ represent the outcome (here, total passengers on the route by year) in the case of a unit (a route) exposed to treatment (change in Law). By analogy, $Y_{0}$ is the outcome if the unit is not exposed to treatment $(D=0)$.

Our interest is defined by the difference between $Y_{1}$ and $Y_{0}$. In our specific case, we are interested in estimating the average effect on passengers of routes affected by changes in Law, which can be defined as:

$$
E\left(Y_{1}-Y_{0} \mid D=1\right)
$$

A set of observable characteristics $(Z)$ affects both treatment status and potential outcomes. Using the conditional independence assumption and a requirement for identification, the Average Treatment effect on the Treated (hereafter, ATT) can be identified as:

$$
\begin{aligned}
& A T T=E\left(Y_{1}-Y_{0} \mid D=1\right)=E\left(E\left(Y_{1}-Y_{0} \mid D=1, Z\right)\right)= \\
& =E\left(E\left(Y_{1} \mid D=1, Z\right)-E\left(Y_{0} \mid D=0, Z\right) \mid D=1\right)
\end{aligned}
$$

The use of the matching estimator pairs up treatment routes (WITH changes in Law) with control routes (WITHOUT changes) that have similar observed attributes. This is one of the main advantages of matching analysis in contrast with the former empirical approach. 
The main hypothesis is whether any unobserved variable exists that we have not included in instrumental variable regression that affects final prices. In our case, we have calculated the average treatment effect on the treated by using the Kernel Matching method. ${ }^{21}$

Table 8 summarizes the matching estimator outcome. In all estimations, we have included as exogenous variables the following (in $\ln$ ): distance, average population and employment. The estimations have been done using the bootstrap option.

Table 8. Summary of results of Matching estimator

\section{Change Average Treatment on Treated (ATT)}

\begin{tabular}{|c|c|}
\hline $\begin{array}{l}\text { First change: Legislative reform in } 2006 \\
\text { (procompetitive) }\end{array}$ & $1.194(0.278)^{* * *}$ \\
\hline $\begin{array}{c}\text { Second change: Legislative reform in } 2011 \\
\text { (restrictive) }\end{array}$ & $-0.296(0.011)$ \\
\hline
\end{tabular}

Note: $* * * 1 \%, * * 5 \%, * 10 \%$ significance test. Standard deviation in brackets

Matching estimations yield to a general outcome: the first change increased the number of passengers moved on those routes, while the second had no effect. These results support the general outcome found in the previous estimations.

Overall, the results of the econometric analysis suggest that the policy reform of 2006 lead to a substantial traffic increase and the policy reform of 2011 lead to a traffic decrease. However, it could also be the case that some traffic increase could have taken place without the change in the regulation in 2006 while the traffic decrease in 2011 could have even greater without the subsidies. Hence, the subsidies may be compensating a negative trend in demand. This is a caveat that must be considered in the interpretation of results. To this point, note that the DiD strategy is based on the analysis of traffic changes in routes affected and not affected by the policy reforms after controlling for exogenous factors that may explain traffic evolution. Hence, our empirical strategy is aimed to deal with the mentioned concern which in any case must be taken into account.

\footnotetext{
${ }^{21}$ Four of the most widely used matching methods are the Nearest Neighbour, Radius, Stratification and Kernel. None of these are a priori superior to the others. See Becker and Ichino (2002) for a further explanation.
} 


\section{Conclusions}

This paper has examined the impact of PSO policies on route traffic for a sample based on routes of the intra-Canarian islands market (Spain). In particular, we have shown that a policy reform in 2006 consistent in relaxing the price setting scheme but imposing higher frequency floors led to a substantial increase in traffic. In contrast, a policy reform in 2011 consistent with restricting entry to the market in exchange for a subsidy to the operating airline on the affected routes did not lead to an increase in traffic.

The link between air transportation and economic growth is well established in the literature and such a link is particularly strong if we consider islands where surface transportation is only an option for mobility within the island. In this regard, it can be argued that public policies to support air services on islands may be required, but the specific objectives of those policies should be well defined. In particular, the implementation of PSO policies in Europe is not usually based on objective criteria regarding definition of the eligible routes, the amount of the subsidy, or the determination of service levels and fares.

For the case analyzed in this paper, we find that the 2006 reform had strong positive effects in terms of the increase of traffic on the treated routes in relation to the control routes. However, several of the routes affected by the reform had at that time a density of traffic high enough to be viable in a free market scenario. Thus, the eligible routes should be selected by ensuring that it really is necessary that they receive public support. In contrast, the 2011 reform did not have any relevant effects in terms of traffic. It may be that this reform avoided a substantial reduction in traffic in very thin routes but it is doubtful whether subsidy size and restriction to market access justifies a policy with modest effects on traffic. 


\section{References}

Albalate, D. (2008) 'Lowering blood alcohol content levels to save lives: the European experience', Journal of Policy Analysis and Management, 27(1), 20-39.

Becker, S. O., Ichino, A. (2002). Estimation of average treatment effects based on propensity scores. The stata journal, 2(4), 358-377.

Betancor, O., Viecens, M.F. (2012) 'Segundo informe del Observatorio de Transporte Aéreo de FEDEA: La competencia en el mercado español de transporte aéreo', Fundación de Estudios de Economía Aplicada, 2012.

Bubalo, B. (2012) 'Social costs of public service obligation routes - calculating subsidies of regional flights in Norway', Netnomics: Economic Research and Electronic Networking, 13(2), 125-140.

Cáceres, R.M. (2010) 'La industria europea del transporte aéreo. Peculiaridades jurídicoeconómicas', Revista de Derecho del Transporte, núm. 5, 43-66.

Calzada, J., Fageda, X. (2012) 'Discounts and Public Service Obligations in the Airline Market: Lessons from Spain', Review of Industrial Organization, 40(4), 291-312.

Calzada, J., Fageda, X. (2014) 'Competition and public service obligations in European aviation markets', Transportation Research Part A: Policy and Practice, vol. 70, 104-116.

Campos, J., Jiménez, J.L., Perdiguero, J. (2015) 'Contestability and public concern about airfares: A case study in the Canary Islands', Transport Policy, vol. 42, 180-186.

Comunidades Europeas. 'Reglamento (CEE) No 3975/87 del Consejo, de 14 de diciembre de 1987, por el que se establecen las normas de desarrollo de las reglas de competencia para empresas del sector del transporte aéreo', Diario Oficial de las Comunidades Europeas, 31 de diciembre de 1987, L 374, 1-8.

Comunidades Europeas. 'Reglamento (CEE) No 3976/87 del Consejo, de 14 de diciembre de 1987, relativo a la aplicación del apartado 3 del artículo 85 del Tratado a determinadas categorías de acuerdos y prácticas concertadas en el sector del transporte aéreo', Diario Oficial de las Comunidades Europeas, 31 de diciembre de 1987, L 374, 9-11.

Comunidades Europeas. 'Directiva No 87/601/CEE del Consejo, de 14 de diciembre de 1987, sobre tarifas para el transporte aéreo regular entre Estados miembros', Diario Oficial de las Comunidades Europeas, 31 de diciembre de 1987, L 374, 12-18.

Comunidades Europeas. 'Decisión No 87/602/CEE del Consejo, de 14 de diciembre de 1987, relativa a la distribución de la capacidad de pasajeros entre compañías aéreas en servicios aéreos regulares entre Estados miembros y al acceso de las compañías aéreas a las rutas de servicios aéreos regulares entre Estados miembros, Diario Oficial de las Comunidades Europeas, 31 de diciembre de 1987, L 374, 19-26. 
Comunidades Europeas. 'Reglamento (CEE) No 2342/90 del Consejo, de 24 de julio de 1990, sobre las tarifas de los servicios aéreos regulares', Diario Oficial de las Comunidades Europeas, 11 de agosto de 1990, L 217, 1-7.

Comunidades Europeas. 'Reglamento (CEE) N 2343/90 del Consejo, de 24 de julio de 1990, relativo al acceso de las compañías aéreas a las rutas de servicios aéreos regulares intracomunitarios y a la distribución de la capacidad de pasajeros entre compañías aéreas en servicios aéreos regulares entre Estados miembros', Diario Oficial de las Comunidades Europeas, 11 de agosto de 1990, L 217, 8-14.

Comunidades Europeas. 'Reglamento (CEE) No 2344/90 del Consejo, de 24 de julio de 1990, por el que se modifica el Reglamento (CEE) N. 3976/87 relativo a la aplicación del apartado 3 del artículo 85 del Tratado de determinadas categorías de acuerdos y prácticas concertadas en el sector del transporte aéreo', Diario Oficial de las Comunidades Europeas, 11 de agosto de 1990, L 217, 15-16.

Comunidades Europeas. 'Reglamento (CEE) No 2407/92 del Consejo, de 23 de julio de 1992, sobre la concesión de licencias a las compañías aéreas', Diario Oficial de las Comunidades Europeas, 24 de agosto de 1992, L 240, 1-7.

Comunidades Europeas. 'Reglamento (CEE) No 2408/92 del Consejo, de 23 de julio de 1992, relativo al acceso de las compañías aéreas de la Comunidad a las rutas aéreas intracomunitarias', Diario Oficial de las Comunidades Europeas, 24 de agosto de 1992, L 240, 8-14.

Comunidades Europeas. 'Reglamento (CEE) No 2409/92 del Consejo, de 23 de julio de 1992, sobre tarifas y fletes de los servicios aéreos', Diario Oficial de las Comunidades Europeas, 24 de agosto de 1992, L 240, 15-17.

España. 'Ley 19/1994, de 6 de julio, de modificación del Régimen Económico y Fiscal de Canarias', Boletín Oficial del Estado, 7 de julio de 1994, núm. 161, 21719-21736.

España. 'Ley 66/1997, de 30 de diciembre, de Medidas Fiscales, Administrativas y del Orden Social', Boletín Oficial del Estado, 31 de diciembre de 1997, núm. 313, 38517 38616.

España. 'Resolución de 30 de julio de 1998, de la Subsecretaría de Estado de Infraestructuras y Transportes, por la que se dispone la publicación del Acuerdo del Consejo de Ministros de 10 de julio de 1998, por el que se declaran Obligaciones de Servicio Público en rutas aéreas entre las Islas Canarias', Boletín Oficial del Estado, 28 de agosto de 1998, núm. 206, 29376-29380.

España. 'Resolución de 28 de noviembre de 2003, de la Subsecretaría, por la que se dispone la publicación del Acuerdo del Consejo de Ministros de 21 de noviembre de 2003, por el que se declaran obligaciones de servicio público en rutas aéreas entre las Islas Baleares', Boletín Oficial del Estado, 4 de diciembre de 2003, núm. 290, 43330-43333.

España. 'Resolución de 21 de julio de 2006, de la Subsecretaría, por la que se dispone la publicación del Acuerdo del Consejo de Ministros de 2 de junio de 2006, por el que se declaran obligaciones de servicio público en rutas aéreas entre las Islas Canarias', Boletin Oficial del Estado, 27 de julio de 2006, núm. 178, 28180-28185. 
España. 'Resolución de 27 de marzo de 2009, de la Subsecretaría, por la que se publica el Acuerdo del Consejo de Ministros de 13 de marzo de 2009, por el que se declaran obligaciones de servicio público en la ruta Almería-Sevilla', Boletín Oficial del Estado, 20 de abril de 2009, núm. 96, 35812-35817.

España. 'Resolución de 25 de noviembre de 2011, de la Subsecretaría, por la que se dispone la publicación del Acuerdo del Consejo de Ministros de 7 de octubre de 2011, por el que se modifica el de 2 de junio de 2006, por el que se declaran obligaciones de servicio público en rutas aéreas entre las Islas Canarias, y se limita el acceso a determinadas rutas', Boletín Oficial del Estado, 2 de diciembre de 2011, núm. 290, 128426-128429.

España. 'Resolución de 22 de junio de 2012, de la Secretaría General de Transportes, por la que se publica el Acuerdo del Consejo de Ministros de 15 de junio de 2012, por el que se declaran obligaciones de servicio público en la ruta aérea Menorca-Madrid', Boletín Oficial del Estado, 23 de julio de 2012, núm. 175, 52759-52765.

Fageda, X., Jiménez, J.L., Díaz, C. (2012) 'Fare differences between domestic and international air markets on routes from Gran Canaria', Journal of Air Transport Management, vol. 25, 8-10.

Fageda, X., Jiménez, J. L., Valido, J. (2016). Does an increase in subsidies lead to changes in airfares? Empirical evidence from Spain. Transportation Research Part A: Policy and Practice, 94, 235-242.

Fageda, X., Jiménez, J.L., Valido, J. (2017) 'An empirical evaluation of the effects of European public policies on airfares in islands', Mimeo.

Hernández, J.A. (2004) 'The role of inter-island air transport in the Canary Islands', Journal of Transport Geography, 12(3), 235-244.

Hernández, J.A. (2010) 'El transporte aéreo interinsular como factor de cohesión territorial en las Islas Canarias', Transporte y Territorio, núm. 2, 38-67.

Merkert, R. and B.O. Fee (2013) 'Efficient procurement of public air services. Lessons learned from European transport authorities perspectives', Transport Policy, 29, 118-125.

Merkert, R. and G. Williams (2013) 'Determinants of European PSO airline efficiency: Evidence from a semi-parametric approach', Journal of Air Transport Management, 29, 1116.

Pita, J.P., Antunes, A.P., Barnhart, C., de Menezes, A.G. (2013) 'Setting public service obligations in low-demand air transportation networks: Application to the Azores', Transportation Research Part A: Policy and Practice, vol. 54, 35-48.

Pita, J.P., Adler, N., Antunes, A.P., (2014) 'Socially-oriented flight scheduling and fleet assignment model with an application to Norway', Transportation Research Part B: Methodological, vol. 61, 17-32.

Ramos, D. (2015) 'Evaluación del impacto de la competencia en un mercado parcialmente protegido: el transporte aéreo interinsular en Canarias (2003-2012)', Revista de Geografía Norte Grande, núm. 61, 135-159. 
Reynolds-Feighan, A. (1995) 'European Air Transport Public Service Obligations: A Periodic Review', Fiscal Studies, 16(1), 58-74.

Rosenbaum, P. R., Rubin, D. B. (1983). The central role of the propensity score in observational studies for causal effects. Biometrika, 70(1), 41-55.

Rubin, D. B. (1974). Estimating causal effects of treatments in randomized and nonrandomized studies. Journal of Educational Psychology, 66(5), 688.

Santana, I. (2009) 'Do Public Service Obligations hamper the cost competitiveness of regional airlines?', Journal of Air Transport Management, 15(6), 344-349.

Unión Europea. 'Reglamento (CE) No 1008/2008 del Parlamento Europeo y del Consejo, de 24 de septiembre de 2008, sobre normas comunes para la explotación de servicios aéreos en la Comunidad (versión refundida)', Diario Oficial de la Unión Europea, 31 de octubre de 2008, L 293, 3-20.

Williams, G., Pagliari, R. (2004) 'A comparative analysis of the application and use of public service obligations in air transport within the EU', Transport Policy, 11(1), 55-66.

Williams, G. (2005) 'European Experience with Direct Subsidization of Air Services', Public Money \& Management, 25(3), 155-161.

Wittman, M.D., F. Allroggen, and R. Malina (2016) 'Public Service Obligations for Air Transport in the United States and Europe: Connectivity Effects and Value for Money', Transportation Research-A, 94, 112-126. 